CASE REPORT

\title{
A Case of Subconjunctival Dirofilariasis in Bulgaria
}

\author{
Nina S. Stoyanova \\ Department of Ophthalmology, Medical Faculty, Medical University of Plovdiv, Plovdiv, Bulgaria
}

\section{Correspondence:}

Nina S. Stoyanova, Department of Ophthalmology, Medical University of Plovdiv, 66 Peshtersko Shosse Blvd., 4002 Plovdiv, Bulgaria

E-mail: nina.st.st@abv.bg

Tel: +359888636067

Received: 25 May 2017

Accepted: 10 Oct 2017

Published Online: 30 Oct 2017

Published: 30 June 2018

Key words: subconjunctival parasitosis, Dirofilaria repens

Citation: Stoyanova NS. A case of subconjunctival dirofilariasis in Bulgaria. Folia Med (Plovdiv) 2018;60(2):323-7.

doi: 10.1515/folmed-2017-0097
We report a case of subconjunctival invasion of Dirofilaria repens in a woman from Southern Bulgaria. Dirofilariasis is an extremely rare parasitic disease for Bulgaria. It occurs as an endemic parasitosis in the Mediterranean countries. It is caused by helminths of the genus Dirofilaria, which are parasites in dogs, cats, foxes, wolves - the final hosts of the parasite. It may very rarely occur in humans, the infection triggered by a bite of bloodsucking mosquitoes, which are the intermediate hosts of Dirofilaria. The clinical forms of dirofilariasis in humans are subcutaneous, pulmonary and ocular, the brain, testes and mammary glands being rarely affected. A 51-year-old patient presented with migrating edema in the area of the left temple and upper eyelid, with redness and swelling of the conjunctiva, as well as a subjective sense of movement under the eyelid of the left eye, lasting for about ten days. The subconjunctival localization of a moving $9.5-\mathrm{cm}$ nematode was established, it was surgically removed and histologically studied. This case of ocular subconjunctival dirofilariasis is of clinical interest due to the rarely observed pathology.

\section{INTRODUCTION}

Dirofilariasis is a widespread zoonosis which occurs in temperate, tropical, and subtropical countries. The genus Dirofilaria ${ }^{1}$ (family Onchocercidae, class Nematodes) includes species which are natural parasites in dogs, cats and wild animals. Six out of a total of 40 Dirofilaria can cause a disease in humans: $D$. immitis, D. repens, D. striata, D. tenuis, D. ursi, and D. spectans ${ }^{2}$, affecting the lungs, subcutaneous tissue, eyes, rarely the brain, testes and mammary glands.

D. immitis is responsible for pulmonary dirofilariasis, while D. repens - for the subcutaneous and ocular forms. Infection occurs after a bite by bloodsucking mosquitoes from the family Culicidae (Anopheles, Aedimorphus, Armigeres, Ochlerotatus, Stegomyia, Culex, Coquillettidia, and Mansonia), which are intermediate hosts of the parasite (vectors). The life cycle of the parasite consists of five larval stages, which develop in the intermediate host (embryo-infective to L3 larva) and in the final host (from L3 to adult). The larval form reaches an invasive stage (L3) in the intermediate host for about 2 weeks depending on the environmental conditions (temperatures above $26^{\circ} \mathrm{C}$ ). ${ }^{3}$ Adult females are usually $100-170 \mathrm{~mm}$ long by 4.6-6.5 $\mathrm{mm}$ wide. Males are smaller (50-70 $\mathrm{mm}$ long by 3.7-4.5 mm wide) (Fig. 1). Species identification of Dirofilariae is based on morphological characteristics of the helminth cross-section. Dirofilaria repens is characterized by external longitudinal ridges, a thick laminated cuticle, thick muscle layer, and the diameter and laterals cords (Figs 2, 3).

Dirofilaria repens is ovoviviparous and produces live microfilariae (300-360 microns long by 6-8 microns wide). The blood of infected animals is full of circulating microfilariae invading the intermediate host by bloodsucking. In the Malpighian tubules of the mosquito, microfilariae moult until they reach an infective larval stage, which depends on the surrounding conditions (ambient temperature and humidity), and then migrate to the mouth of the mosquito.

When an infected mosquito bites, the infectious larvae fall under the skin of the final host (animals), migrate and reach maturity; mature females emit live microfilariae which circulate in the bloodstream. ${ }^{4}$ Humans are accidental hosts of dirofilariae. After a 


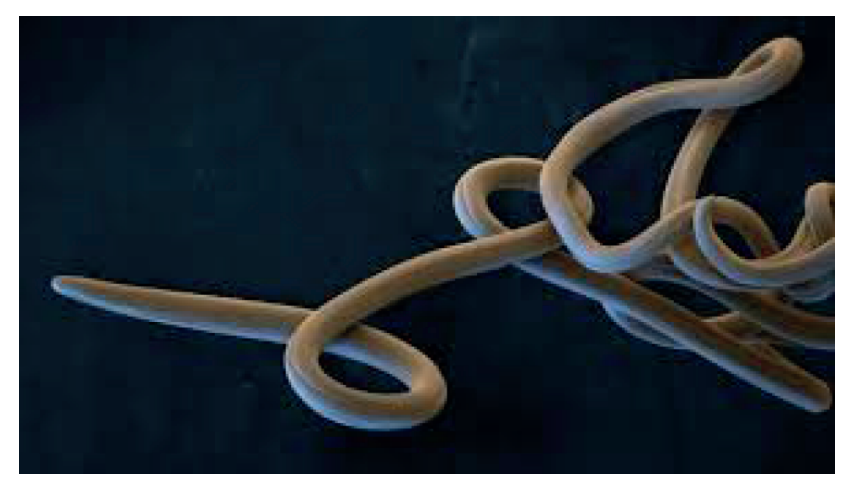

Figure 1. Dirofilaria repens - adult form.

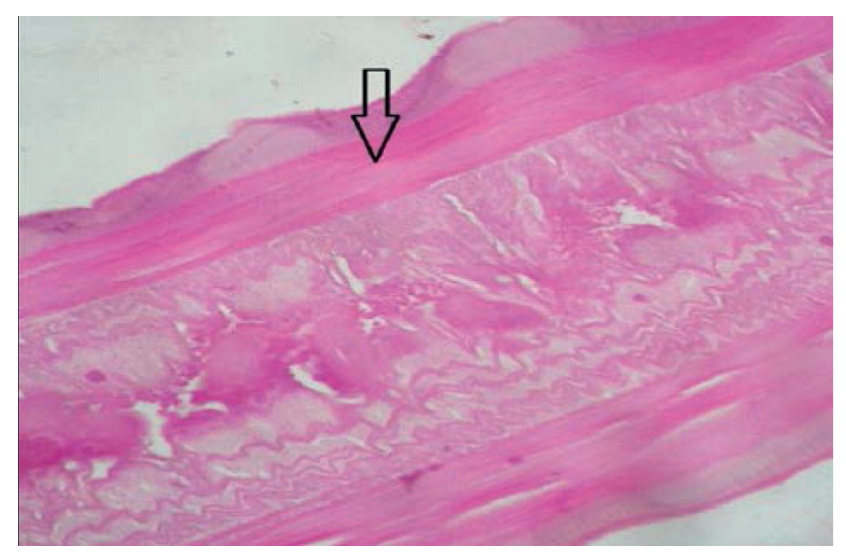

Figure 2. Longitudinal section of the worm showing a thick muscle layer (arrow) (H\&E stain, $\times 400)$.

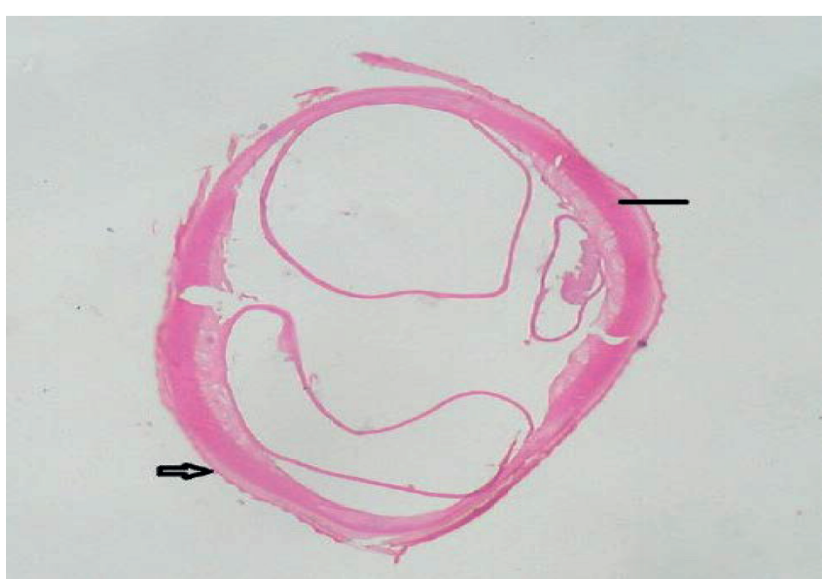

Figure 3. Transverse section of the worm with a characteristic multilayered outer cuticle, external longitudinal ridges (arrow) and a thick muscle layer (line) (H\&E stain, $\times 400)$. human gets bitten, microfilariae usually die in the subcutaneous tissue, and it is on very rare occasions that surviving larvae develop into immature adult forms, reproductively inactive and unable to produce new microfilariae, i.e. the infection is not contagious in humans. The incubation period lasts 27 to 34 weeks. Adult forms live in their hosts for several years. ${ }^{5-7}$

In the eye, dirofilariae can be found subconjunctivally, in Tenon's capsule, in the periorbital tissues (eyelids, orbit) and intraocularly - in the anterior chamber and the vitreous. ${ }^{5-7}$ Microfilariae enter the vitreous and the anterior chamber through the bloodstream, and adult forms can be found subcutaneously in the eyelids, the orbit or under the conjunctiva during the parasite's migration.

\section{CASE REPORT}

This case of subconjunctival dirofilariasis presents a woman aged 51, a seamstress, whose complaints started on July 2, 2015, with the occurrence of edema in the area of the left temple, which subsequently moved to the area of the upper eyelid. After treatment with tobramycin/dexamethasone, the eyelid swelling subsided only to be replaced by irritation, redness and foreign body sensation in the left eye. The patient denied traumas, bites or any trips abroad. She has got a dog, which she keeps in the yard.

A comprehensive eye examination was performed, which established normal visual acuity and IOP of both eyes. Biomicroscopy exposed a moving white parasite in the left eye, located subconjunctivally, temporally (Fig. 4). No pathological changes in the fundus of either eye were established. All blood indicators were within the reference range. Tests for filarial antibody and microfilaremia were negative. After a consultation with an internist and a cardiologist, concomitant arterial hypertension and ischemic heart disease were diagnosed.

The parasite was carefully removed with two tweezers, through a small conjunctival incision, under local anaesthesia (epibulbar solution of proxymetacaine hydrochloride and 2\% lidocaine hydrochloride subconjunctivally), after which it was sent for a morphological and parasitological examination. Macroscopically, the parasite was seen in motion, white in colour, $9.5 \mathrm{~cm}$ long and about $0.4 \mathrm{~cm}$ wide (Fig. 5). Histopathological section of the worm showed thick cuticle with external longitudinal cuticular ridges and a thick muscle layer. Based on the morphologic features, the worm was 


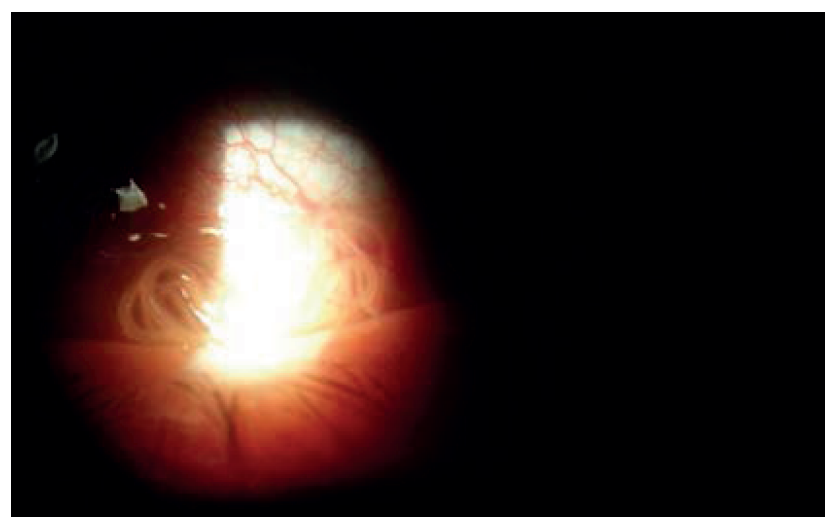

Figure 4. Biomicroscopy - a subconjunctivally located parasite.

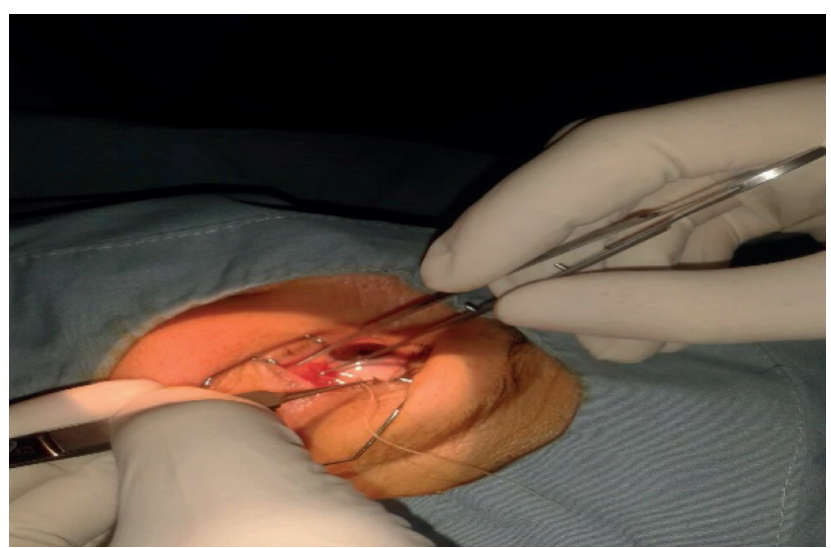

Figure 5. Surgical removal of the parasite.

identified as Dirofilaria repens.

Postoperatively, topical treatment with tobramycin/dexamethasone eye drops and ointment, methylprednisolone acetate $40 \mathrm{mg}$ intravenously for 3 days and desloratadine 1 tablet daily were applied.

A year later, the patient had subjective complains of dryness and discomfort in both eyes, which she associated with epidemic keratoconjunctivitis she suffered for several months after the removal of the parasite, as well as of an increased incidence of leg edema. After the conducted tests, we established normal visual acuity of both eyes, old corneal nummular nubeculae, a calm conjunctiva and fundi without any pathological changes; the complete blood count and the blood differential test showed values within the reference range; no eosinophilia was found; during the parasitological examination of a thick drop of blood, no microfilariae were found; the abdominal ultrasound scan showed no abnormalities.
A consultation with a dermatologist was done finding no skin lesions. After the examination with a vascular surgeon, chronic venous insufficiency was established as the cause of the leg edema. The patient was discharged without any topical eye therapy.

\section{DISCUSSION}

The spread of dirofilariasis depends on the presence of vector mosquitoes. Their development and survival is directly related to the favourable climatic conditions. ${ }^{3}$ This parasitosis occurs in temperate, tropical and subtropical countries. By 2001, dirofilariasis was mainly found in Southern Europe - in countries like Spain, Portugal, Italy, France ${ }^{8}$, Greece and Turkey. As of 2011, the data shows that the disease has been spreading across Eastern and Central Europe.

The largest number of cases have been described in Italy, followed by France, Greece and Spain. Although dirofilariasis is considered endemic in these countries, reports have been published from many parts of the world like Africa, Australia, America, Europe $^{9,10}$ and Asia. There are reported cases of ocular dirofilariasis in Serbia ${ }^{11}$, Denmark, Russia, Tunisia and Greece ${ }^{5}$. Within the last 6-7 years, cases of ocular dirofilariasis have also been described in India, which is considered a non-endemic country. 5,12 Of all the reported cases of ocular dirofilariasis, the subconjunctival localization $(60 \%)$ is most common, followed by eyelid and orbital dirofilariasis (about $25 \%){ }^{5} \mathrm{~A}$ case of dirofilariasis in the anterior chamber has been reported by Chopra et al. in India. ${ }^{12}$

Kalogeropoulos et al. published a series of 8 cases, two of which are of dirofilariasis with localization in the vitreous, one in the orbit and 5 subconjunctivally. ${ }^{5}$ The ocular symptoms are manifested by discomfort, eye pain and redness. In some reports, conjunctival dirofilariasis is misdiagnosed as allergic conjunctivitis. The orbit and eyelid forms are less common, being manifested with edema and hyperemia of the eyelids, rarely with exophthalmos and diplopia; when localized in the vitreous, dirofilariasis develops clinically as uveitis (uveoretinitis, neurouveitis).

The treatment involves surgical removal of the parasite. When localized subconjunctivally, after local anesthesia and an incision of the conjunctiva, the whole parasite is carefully removed in order to prevent an allergic reaction to parasitic residues. Intraocular Dirofilaria is removed through vitrectomy. No specific subsequent anthelmintic treatment is necessary, since $D$. repens is non-reproductive in humans, no microfilariae are produced, and the 
removal of the adult parasite is sufficient etiological treatment.

In order to establish a diagnosis, the parasitological and morphological study of the parasite matters as well. Of the blood indicators, eosinophilia causes suspicion - it occurs in less than $15 \%$ of the cases with $D$. immitis and rarely with $D$. repens. Blood smears (the microscopy of a thick drop of blood) to detect microfilariae are usually negative.

Dirofilariasis is a rare parasitosis for Bulgaria. $D$. repens is a parasite endemic to the Mediterranean countries. The transmission of the filarial worms is dependent on the availability of microfilariaemic hosts, competent mosquito vectors and suitable temperatures for the development of the infectious stages in the mosquito (L3). The extrinsic development to the infectious third larval stage takes about $10-12$ days at $24-26^{\circ} \mathrm{C}$ but as long as 29 days at $18^{\circ} \mathrm{C}$. Successful transmission of filariae to a host requires an infected mosquito to survive longer than the duration of the extrinsic incubation period. The maximal life span of mosquitos is 30 days. Climate change, the increasing average annual temperatures, the occurrence of favourable factors for the development and activity of vector mosquitoes, as well as trips to endemic countries, have led to the spread of the parasitosis to more geographical regions. Humans are accidental hosts to the parasite, and despite its rare ocular localization, dirofilariasis has to be included in the differential diagnostic plan of eye diseases.

\section{REFERENCES}

1. Nath R, Gogoi R, Bordoloi N, et al. Ocular dirofi- lariasis. Indian J Pathol Microbiol 2010;53:157-9.

2. Aspöck H. Dirofilaria and dirofilarioses. Introductory remarks; Proceedings of Helminthological Colloquium; 14th November; Vienna. 2003. p. 5.

3. Simón F, Siles-Lucas M, Morchón R, et al. Human and animal dirofilariasis: The emergence of a zoonotic mosaic. Clin Microbiol Rev 2012;25:507-44.

4. Manfredi MT, Cerbo A, Genchi M. Biology of filarial worms parasitizing dogs and cats. Journal Mappe Parassitologiche 2007;8:39-44.

5. Kalogeropoulos K, Stefaniotou M, Gorgoli K, et al. Ocular dirofilariasis: A case series of 8 patients. Middle East Afr J Ophthalmol 2014;21(4):312-6.

6. Melsom H, Kurtzhals J, Qvortrup K, et al. Subconjunctival Dirofilaria repens infestation: a light and scanning electron microscopy study. Open Ophthalmology J 2011;5:21-4.

7. Gorezis S, Psilla M, Asproudis I, et al. Intravitreal dirofilariasis: A rare ocular infection. Orbit 2006;25:57-9.

8. Agry N, Sabou M, Billing A, et al. A first human case of ocular dirofilariosis due to Dirofilaria repens in Northeastern France. J Trop Med 2011;2011:698647.

9. Poppert S, Hodapp M, Krueger A, et al. Dirofilaria repens infection and concomitant meningoencephalitis. Emerg Infect Dis 2009;15(11):1844-6.

10. Popescu I, Tudose I, Racz P, et al. Human Dirofilaria repens infection in Romania: A case report. Case Rep Infect Dis 2012:ID 472976. doi:10.1155/2012/472976.

11. Dzamiæ AM, Coloviæ IV, Arsiæ-Arsenijeviæ VS, et al. Human Dirofilaria repens infection in Serbia. J Helminthol 2009;83:129-372.

12. Chopra R, Bhatti SM, Mohan S, et al. Dirofilaria in the anterior chamber: A rare occurrence. Middle East Afr J Ophthalmol 2012;19:349-51. 


\title{
Случай субконъюнктивального дирофиляриоза в Болгарии
}

\author{
Нина С. Стоянова
}

Кафедра офтальмологии, Медицинский факультет, Медицинский университет - Пловдив, Пловдив, Болгария

Адрес для корреспонденции: Нина С. Стоянова, Кафедра офтальмологии, Медицинский университет - Пловдив, бул. „Пещерско шосе“ № 66, 4002, Пловдив, Болгария

E-mail: nina.st.st@abv.bg Tel: +359888636067

Дата получения: 25 мая 2017 Дата приемки: 10 октября 2017 Дата онлайн публикации: 30 октября 2017

Дата публикации: 30 июня 2018

Ключевые слова: субконъюнктивальный паразитоз, Дирофилярия репенс

Образец цитирования:

Stoyanova NS. A case of subconjunctival dirofilariasis in Bulgaria. Folia Med (Plovdiv) 2018;60(2):323-7.

doi: 10.1515/folmed-2017-0097
Мы сообщаем о случае субконъюнктивальной инвазии Дирофилярии репенс у женщины из Южной Болгарии. Дирофиляриоз - чрезвычайно редкая паразитарная болезнь для Болгарии. Она распространена как эндемический паразитоз в странах Средиземноморья. Болезнь вызывается гельминтами рода Дирофилярия, которые являются паразитами у собак, кошек, лисиц, волков - которые являются окончательными хозяевами паразита. Заболевание встречается очень редко у людей. Инфекция вызывается укусом кровососущих комаров, которые являются промежуточными хозяевами Дирофилярии. Клинические формы дирофиляриоза у людей являются подкожными, лёгочными и глазными, в то время как мозг, семенники и молочные железы редко поражаются. 51-летняя больная поступила с мигрирующим отеком в области левого виска и верхнего века, с покраснением и припухлостью конъюнктивы, а также ощущала субъективное чувство движения под веком левого глаза, продолжающееся около десяти дней. Установлена субконъюнктивальная локализация движущейся 9.5-см нематоды, которую хирургически удалили и гистологически исследовали. Этот случай окулярного субконъюнктивального дирофиляриоза представляет клинический интерес из-за редко наблюдаемой патологии. 